\title{
24. ROCK MAGNETIC STUDY OF SEDIMENTS FROM SITE 808, LEG $131^{1}$
}

\author{
R. Lu, ${ }^{2}$ S.K. Banerjee, ${ }^{2}$ M. Jackson, ${ }^{2,3}$ and J. Marvin ${ }^{2}$
}

\begin{abstract}
Shipboard magnetic investigation showed two zones of weak natural remanent magnetization (NRM): $675-925$ and 1080-1243 meters below sea floor. Within these two sections, NRM intensity decreases by one to two orders of magnitude. Additional magnetic measurements onshore have shown similar fluctuations for NRM and saturation magnetization $\left(J_{s}\right)$. $J_{s}$ becomes almost zero in the low-NRM intensity zones, indicating a small magnetic content. The variation of relative magnetic grain sizes have been examined by the ratio of $\mathrm{ARM} / K_{0}$ (anhysteretic remanent magnetization to low magnetic field susceptibility) and by partial ARM (pARM) measurements. Both results indicate difference in magnetic grain sizes between the high- and low-intensity zones.

For these Site 808 sediments, we have not found any correlation between magnetic intensity variation and sediment units. In addition, the calcite content varies only by a factor of 1.5 at the most, rather than 1 to 2 orders of magnitude, and therefore calcite dilution can not account for the low intensities. Because the changes in sediment sources and compositions can not explain these unusual magnetic phenomena, we suggest that the low-intensity zones may be interpreted in terms of deep-seated diagenetic alteration. Our study points out that (1) it may be difficult to establish a magnetostratigraphy for deep sediments due to extremely low NRM intensity, and (2) sudden decreases in NRM intensity may not result from an unusually low paleomagnetic field intensity.
\end{abstract}

\section{INTRODUCTION}

Site 808 was located on the toe of the accretionary prism at the Nankai Trough $\left(32^{\circ} 21.11^{\prime} \mathrm{N}, 134^{\circ} 56.67^{\prime} \mathrm{E}\right)$, where sediments are being delivered by both the northwest movement of the Philippine Sea Plate and the turbidity currents along the Nankai Trench. The upper part of the sediments, about $550 \mathrm{~m}$ thick, is dominated by turbidites, whereas the lower part, about $700 \mathrm{~m}$ thick, is dominated by hemipelagic deposits (Taira, Hill, Firth, et al., 1991). The penetration at Site 808 was to $1327.0 \mathrm{mbsf}$, including the entire toe and part of the oceanic basalts. The core recovery was relatively good, which allowed various detailed observations.

Shipboard magnetic measurements were conducted to establish a magnetostratigraphy for the sediment age control and to provide structural geologists with core orientation data. The measurements were made on the archive halves of the cores with the shipboard cryogenic magnetometer. Within the limits of core recovery, a continuous downhole variation of NRM was obtained. AF demagnetization was also applied to the sediments to test the stability of NRM. Figure 1 shows the magnetic inclination and intensity with zero and 10-mT AF demagnetization.

Magnetic inclinations show both positive and negative values at shallow depth (0-100 mbsf) prior to AF demagnetization (Fig. 1A), but become positive after 10-mT AF demagnetization (Fig. 1B), indicating a large magnetic overprint. This component is suspected to have been acquired during the coring process in the soft sediments. At about 365 mbsf, inclinations appear negative even after AF demagnetization. It is suggested from structural studies (Taira, Hill, Firth, et al., 1991) that this is produced by the frontal thrust fault, which intensively deformed the sediments and turned them upside down, resulting in this artificial "reversal event." Below 700 mbsf, inclinations become quite scattered, especially when soft overprints are removed by AF demagnetization (Fig. 1B). They range from $75^{\circ}$ to $-75^{\circ}$, and change sign frequently, which makes magnetostratigraphic

\footnotetext{
' Hill, I.A., Taira, A., Firth, J.V., et al., 1993. Proc. ODP, Sci. Results, 131: College Station, TX (Ocean Drilling Program).

${ }^{2}$ Institute for Rock Magnetism and Department of Geology and Geophysics, University of Minnesota, Minneapolis, MN 55455, U.S.A.

${ }^{3}$ Current address: Twin Cities Research Center, U.S. Bureau of Mines, Minneapolis, MN 55417, U.S.A.
}

interpretation very difficult. The only clear magnetic polarity boundary is the Brunhes-Matuyama at 657 mbsf.

On the other hand, magnetic intensity results show a striking feature with or without AF demagnetization. There are two clear-cut zones of low NRM intensity: 675-925, and 1080-1243 mbsf (Fig. 1C, -D). At $675 \mathrm{mbsf}, \mathrm{NRM}$ intensity decreases sharply to almost zero, then slowly increases with depth but remains low until 925 mbsf. Intensity decreases again at $1080 \mathrm{mbsf}$, reaching a minimum before the acidic volcaniclastic deposits are reached at 1243 mbsf. The high-intensity layer sandwiched between the two low-intensity zones seems to have gradational boundaries. Similar large downhole intensity decreases were also observed in Leg 87 (Kagami, Karig, Coulbourn, et al., 1986), Leg 110 (Mascle, Moore, et al., 1988), and Leg 124 (Rangin, Silver, et al., 1989). This may indicate a general problem with deep sediments that have very weak magnetic signals.

The primary purpose of this preliminary study is to investigate these unusual magnetic properties, with an emphasis on magnetic intensity. The results of more detailed experiments in progress will be published separately. By our efforts, we also hope to clarify the roles of the hydrologic system and structures in the Nankai Trench area, especially the décollement, on controlling magnetic minerals.

\section{SAMPLING PROCESS AND EXPERIMENTAL METHOD}

During the cruise, individual oriented samples were taken in the relatively undisturbed working halves of the cores (Table 1). The $z$-axis paralleled the drilling direction, and the $x$-axis was outward perpendicular to the cutting-surface of the cores. In soft sediment sections, samples were taken by pushing the ODP standard sample boxes $\left(6.06 \mathrm{~cm}^{3}\right)$ into the sediments until the boxes were just filled. Then a sharp knife was inserted to cut off the sediment columns and to support the samples during removal. In lithified sedimentary sections, cylindrical samples $\left(11.3 \mathrm{~cm}^{3}\right)$ were taken with a minicore drill. After the sampling process, all specimens were immediately sealed in plastic bags and kept in cold storage aboard the drilling vessel to protect against alterations.

Before measurement, all samples were stored in a zero-field space for 2 months to remove viscous remanent magnetization (VRM) acquired when samples had been exposed to the Earth's magnetic field after coring. All magnetic measurements were made in the Institute 

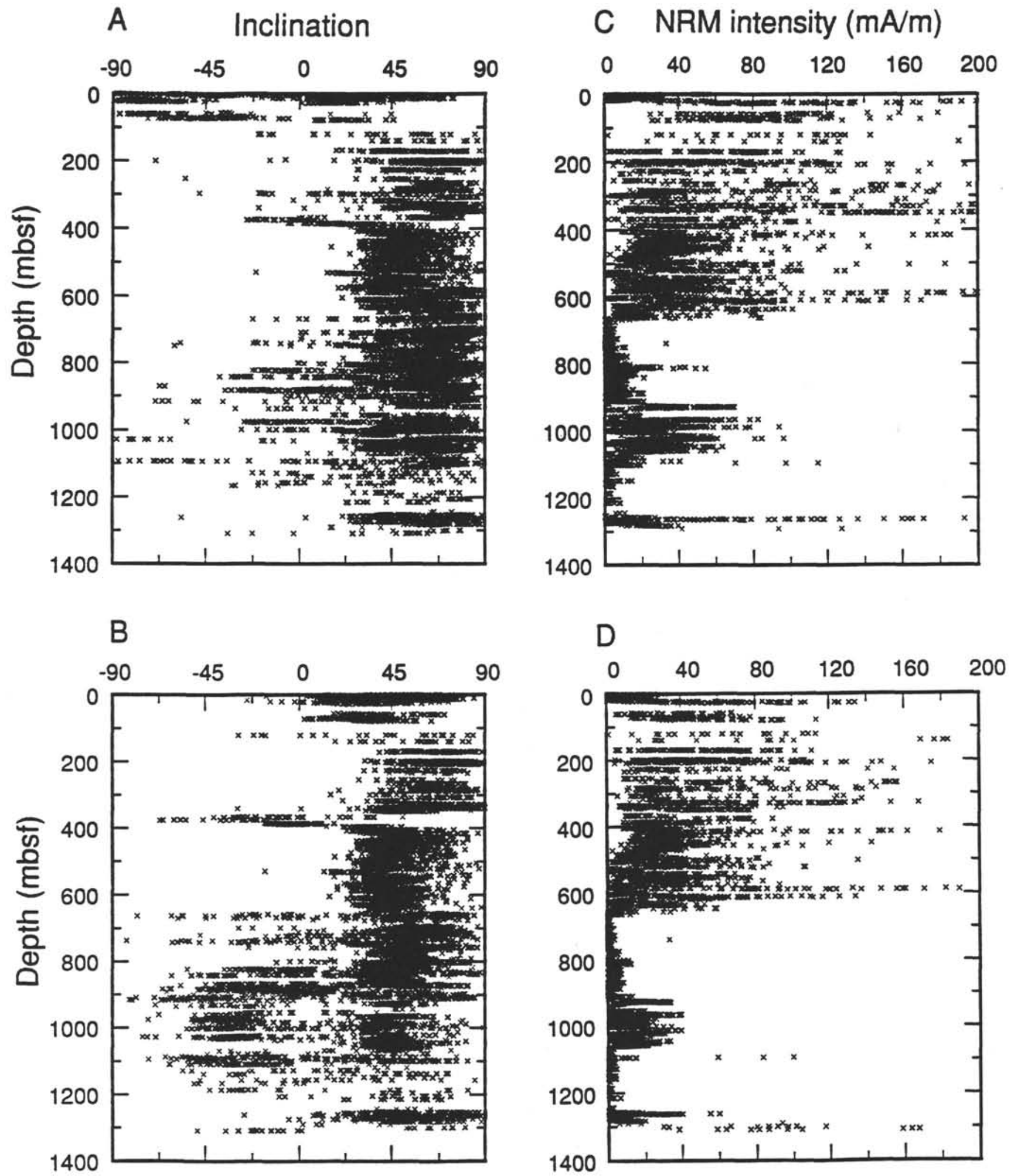

Figure 1. Shipboard magnetic measurements. (A) and (C) are NRM intensity and inclination plots at zero-demagnetization, whereas (B) and (D) are at 10-mT demagnetization. Clearly, there are two magnetic low-intensity zones (A, -B) - 675 to 925 and 1080 to 1243 mbsf, within which the intensity decreases by 1 to 2 orders of magnitude. 
Table 1. Natural remanent magnetization (NRM) results for the individual samples from Site 808. Every sample is $2 \mathrm{~cm}$ long. The sample no., A-1-4-91, for example, stands for Hole 808A, Core 1, Section 4, and interval of $91-93 \mathrm{~cm}$.

\begin{tabular}{|c|c|c|c|c|c|c|c|c|c|c|c|}
\hline $\begin{array}{c}\text { Sample } \\
\text { no. }\end{array}$ & $\begin{array}{l}\text { Depth } \\
\text { (mbsf) }\end{array}$ & Inclination & $\begin{array}{l}\mathrm{NRM} \\
(\mathrm{A} / \mathrm{m})\end{array}$ & $\begin{array}{c}\text { Sample } \\
\text { no. }\end{array}$ & $\begin{array}{l}\text { Depth } \\
\text { (mbsf) }\end{array}$ & Inclination & $\begin{array}{l}\mathrm{NRM} \\
(\mathrm{A} / \mathrm{m})\end{array}$ & $\begin{array}{c}\text { Sample } \\
\text { no. }\end{array}$ & $\begin{array}{l}\text { Depth } \\
\text { (mbsf) }\end{array}$ & Inclination & $\begin{array}{l}\text { NRM } \\
(\mathrm{A} / \mathrm{m})\end{array}$ \\
\hline \multirow[t]{2}{*}{$131-808-$} & & & & B-11-1-56 & 207.37 & 36.0 & 0.019 & C- $50-5-111$ & 777.52 & 47.0 & 0.003 \\
\hline & & & & B-11-3-20 & 210.01 & 60.0 & 0.040 & C-52-2-101 & 792.32 & 80.1 & 0.002 \\
\hline A-1-1-49 & 0.50 & 26.0 & 0.037 & B-16-1-40 & 254.81 & 58.0 & 0.103 & C-53-3-99 & 803.40 & -49.9 & 0.007 \\
\hline A-1-1-96 & 0.97 & 40.0 & 0.002 & B-19-2-133 & 231.34 & 44.0 & 0.023 & C- $53-4-77$ & 804.68 & 24.0 & 0.001 \\
\hline A-1-4-91 & 5.42 & 16.0 & 0.001 & B-20-2- 25 & 289.66 & -13.0 & 0.041 & C- $54-2-95$ & 811.56 & 27.7 & 0.007 \\
\hline A-2-1-43 & 6.74 & 31.0 & 0.005 & B-22-1-29 & 307.40 & 6.0 & 0.012 & C- $55-3-16$ & 821.87 & 44.4 & 0.003 \\
\hline A-2-1-99 & 7.30 & 1.0 & 0.005 & B-24-1-49 & 326.90 & 60.0 & 0.015 & C- $-56-1-30$ & 828.71 & 83.0 & 0.006 \\
\hline A-2-2-73 & 8.54 & 19.0 & 0.008 & B-24-1-106 & 327.47 & 76.0 & 0.314 & C-56-5-51 & 834.92 & 85.8 & 0.005 \\
\hline A-2-2-97 & 8.78 & 44.0 & 0.025 & B-24-2-106 & 328.97 & 69.0 & 0.101 & C-57-3-112 & 842.23 & -41.2 & 0.010 \\
\hline A-2-3-45 & 9.76 & 45.0 & 0.000 & C- $6-1-70$ & 347.31 & 63.0 & 0.026 & C- $57-5-26$ & 844.37 & 37.0 & 0.003 \\
\hline A-2-4-93 & 11.74 & 23.0 & 0.008 & C-6-3-83 & 350.44 & 60.0 & 0.128 & C- $58-1-46$ & 847.87 & 65.9 & 0.007 \\
\hline A- $-2-5-45$ & 12.76 & 56.0 & 0.002 & $C-12-1-61$ & 405.22 & 23.0 & 0.019 & C-58-5-14 & 853.55 & 44.0 & 0.006 \\
\hline A-2-5-112 & 13.43 & 40.0 & 0.003 & C- $12-2-98$ & 406.09 & 37.0 & 0.022 & C-59-2-45 & 859.06 & 17.0 & 0.003 \\
\hline A-2-6-95 & 14.76 & 28.0 & 0.010 & $C-13-1-46$ & 414.47 & 28.0 & 0.072 & C- $59-3-124$ & 861.35 & 36.2 & 0.006 \\
\hline A- $2-7-24$ & 15.55 & -7.0 & 0.011 & C-15-1-102 & 434.73 & 38.0 & 0.026 & C- $60-2-108$ & 869.39 & 58.0 & 0.002 \\
\hline A-3-1-42 & 16.23 & -59.0 & 0.004 & C- $15-5-42$ & 440.13 & 56.0 & 0.011 & C- $60-3-56$ & 870.37 & 79.2 & 0.003 \\
\hline A-3-1-100 & 16.81 & -53.0 & 0.002 & $C-17-1-26$ & 452.97 & 39.0 & 0.034 & C-61-3-38 & 879.89 & 43.0 & 0.004 \\
\hline A-3-2-93 & 17.14 & 1.0 & 0.028 & C-18-1-93 & 463.34 & 27.0 & 0.067 & C- $62-2-28$ & 887.89 & 81.0 & 0.005 \\
\hline A-3-2-136 & 18.57 & 5.0 & 0.011 & C- $18-2-89$ & 464.80 & 50.0 & 0.016 & C- $62-3-92$ & 890.03 & 84.0 & 0.012 \\
\hline A-3-3-54 & 19.25 & -16.0 & 0.013 & C-19-1-94 & 472.95 & 49.0 & 0.015 & C- $62-5-50$ & 892.61 & 80.0 & 0.015 \\
\hline A-3-3-107 & 19.78 & -50.0 & 0.027 & C-20-2-135 & 484.56 & 47.0 & 0.033 & C- $63-2-72$ & 897.03 & 2.0 & 0.001 \\
\hline A-3-5-92 & 22.63 & 49.0 & 0.029 & C-21-3-141 & 495.72 & 49.0 & 0.055 & C- $64-4-27$ & 910.28 & 64.0 & 0.002 \\
\hline A- $3-6-24$ & 23.05 & 10.0 & 0.112 & C-22-2-101 & 503.52 & 38.0 & 0.123 & C- $65-1-20$ & 915.31 & 47.3 & 0.009 \\
\hline A-3-6-81 & 24.02 & -44.0 & 0.028 & C-23-1-56 & 511.27 & 31.0 & 0.036 & C- $-66-1-32$ & 925.13 & 68.0 & 0.018 \\
\hline A-4-1-88 & 26.19 & 28.0 & 0.065 & C- $26-3-61$ & 543.32 & 50.0 & 0.083 & C- $-67-2-6$ & 936.07 & -39.5 & 0.014 \\
\hline A- $4-1-90$ & 26.21 & 16.0 & 0.089 & C-26-5-72 & 546.43 & 42.0 & 0.006 & C $-68-1-32$ & 944.53 & 69.0 & 0.013 \\
\hline A-4-1-91 & 26.22 & 17.0 & 0.084 & C- $27-4-109$ & 554.90 & 38.0 & 0.024 & C- $69-1-141$ & 955.22 & 17.8 & 0.015 \\
\hline A-4-1-94 & 26.25 & 17.0 & 0.092 & C- $27-6-11$ & 556.92 & 44.0 & 0.038 & C- $70-2-143$ & 966.34 & 64.0 & 0.023 \\
\hline$A-4-1-97$ & 26.28 & 9.0 & 0.100 & C-28-4-102 & 564.43 & 43.0 & 0.005 & C-70-3-95 & 967.36 & 44.1 & 0.056 \\
\hline A-4-1-103 & 26.34 & 12.0 & 0.111 & C- $-30-2-145$ & 581.26 & 54.0 & 0.007 & C- $-70-5-12$ & 969.53 & 71.7 & 0.017 \\
\hline A-4-1-107 & 26.38 & 1.0 & 0.051 & C- $31-1-146$ & 589.07 & 38.0 & 0.050 & C- $71-1-135$ & 974.46 & -2.0 & 0.011 \\
\hline A-6-1-54 & 44.85 & 5.0 & 0.027 & C- $32-2-20$ & 599.01 & 55.0 & 0.010 & C- $71-2-44$ & 975.05 & -11.0 & 0.005 \\
\hline A- $9-1-40$ & 68.71 & 5.0 & 0.056 & C- $32-3-43$ & 600.74 & 42.0 & 0.062 & C-71-3-93 & 977.04 & -17.4 & 0.014 \\
\hline A- $-9-1-87$ & 69.18 & -1.0 & 0.019 & C-33-2-42 & 608.83 & 49.0 & 0.016 & C- $-72-1-35$ & 983.16 & 48.0 & 0.003 \\
\hline A- $9-2-89$ & 70.70 & 6.0 & 0.019 & C-33-3-90 & 610.81 & 62.0 & 0.045 & C- $72-2-143$ & 985.74 & 46.0 & 0.030 \\
\hline A-9-3-53 & 71.84 & -5.0 & 0.087 & C-33-5-94 & 613.85 & 51.0 & 0.075 & C- $72-3-141$ & 987.12 & 52.4 & 0.008 \\
\hline A-9-3-104 & 72.35 & 39.0 & 0.010 & C- $34-2-118$ & 619.19 & 43.0 & 0.007 & C- $72-C C-3$ & 991.90 & 41.0 & 0.034 \\
\hline A-9-4-133 & 74.14 & -6.0 & 0.029 & C-34-4-135 & 622.36 & 60.0 & 0.004 & C-73-2-96 & 994.57 & 53.0 & 0.008 \\
\hline A-9-5-4 & 74.35 & -4.0 & 0.067 & C- $-35-2-97$ & 628.68 & 38.0 & 0.008 & C-73-3-25 & 995.36 & 40.6 & 0.021 \\
\hline A-9-5-12 & 74.43 & 20.0 & 0.061 & C-35-3-21 & 629.42 & 44.0 & 0.006 & C- $73-5-7$ & 998.18 & 33.3 & 0.001 \\
\hline A- $10-1-10$ & 77.91 & 23.0 & 0.068 & C- $35-5-37$ & 632.58 & 41.0 & 0.026 & C- $74-2-72$ & 1003.03 & 46.2 & 0.014 \\
\hline A-10-1-101 & 78.02 & 14.0 & 0.021 & C-36-1-59 & 636.50 & 53.0 & 0.061 & C- $-75-1-7$ & 1011.38 & 39.8 & 0.049 \\
\hline A- $10-2-76$ & 80.07 & 30.0 & 0.106 & C-36-5-44 & 642.82 & 66.0 & 0.008 & C-76-1-44 & 1020.95 & 56.0 & 0.047 \\
\hline A-11-2-52 & 89.43 & 4.0 & 0.080 & C- $38-1-26$ & 655.19 & 66.8 & 0.020 & C- $76-3-44$ & 1023.95 & 80.3 & 0.022 \\
\hline A-13-2-62 & 107.87 & 11.0 & 0.048 & C- $38-2-142$ & 657.83 & 44.0 & 0.007 & C-76-5-24 & 1026.75 & 70.6 & 0.013 \\
\hline A-13-2-105 & 108.30 & 8.0 & 0.166 & C- $38-6-73$ & 663.14 & 85.0 & 0.154 & C- $78-4-82$ & 1044.43 & 60.0 & 0.010 \\
\hline A-13-3-74 & 109.49 & -1.0 & 0.135 & C- $39-4-72$ & 669.73 & -68.0 & 0.000 & C- $79-2-102$ & 1050.83 & 43.0 & 0.031 \\
\hline B-7-1-92 & 169.73 & 38.0 & 0.092 & $C-41-2-67$ & 685.98 & 23.0 & 0.000 & C- $79-3-142$ & 1052.73 & 35.0 & 0.041 \\
\hline B-9-1-41 & 188.62 & 33.0 & 0.057 & C- $43-1-103$ & 704.24 & 24.0 & 0.001 & C- $84-2-16$ & 1093.67 & -34.0 & 0.001 \\
\hline B-9-1-142 & 189.63 & 42.0 & 0.072 & C- $43-3-85$ & 707.06 & 13.0 & 0.000 & C- $85-3-27$ & 1101.57 & 25.0 & 0.001 \\
\hline B- $9-2-54$ & 190.25 & 47.0 & 0.075 & C- $45-3-100$ & 726.01 & 55.0 & 0.000 & C-88-1-49 & 1127.40 & 48.0 & 0.010 \\
\hline B-9-3-80 & 192.01 & 32.0 & 0.034 & C- $-46-1-59$ & 732.30 & 59.0 & 0.001 & C- $94-2-14$ & 1186.55 & 52.0 & 0.001 \\
\hline B- $9-4-48$ & 193.19 & 39.0 & 0.064 & C- $-47-1-78$ & 742.19 & 59.0 & 0.000 & C- $100-2-25$ & 1244.66 & 49.0 & 0.005 \\
\hline B-10-1-49 & 197.90 & 57.0 & 0.035 & C- $-47-5-71$ & 747.90 & -64.0 & 0.000 & C-102-2-1II & 1264.12 & 73.0 & 0.023 \\
\hline B-10-3-19 & 200.60 & 55.0 & 0.024 & C- $-48-3-100$ & 755.11 & 67.0 & 0.002 & C-103-2-53 & 1272.94 & 66.0 & 0.019 \\
\hline B-10-3-89 & 201.30 & 73.0 & 0.114 & C- $49-2-107$ & 763.28 & 43.0 & 0.002 & C-104-2-27 & 1282.18 & 76.0 & 0.047 \\
\hline B- $10-4-50$ & 202.41 & 51.0 & 0.023 & C- $-49-3-54$ & 764.25 & 73.0 & 0.000 & & & & \\
\hline
\end{tabular}

for Rock Magnetism at the University of Minnesota. NRM and its changes during $A F$ demagnetization were first measured with an 2-G cryogenic magnetometer. AF demagnetization steps were 10-15 mT, up to a peak of $100 \mathrm{mT}$. Each of the orthogonal components of NRM was measured twice to obtain accurate remanent intensity, inclination, and declination.

Following NRM measurements, ARM and pARM measurements were made. The high-coercivity baseline remanence was established by $\mathrm{AF}$ demagnetization at $100 \mathrm{mT}$ along three orthogonal axes. ARM was then acquired along the $y$-axis by exposing samples to a $0.1-m T D C$-field, which was superimposed on an AF field decreasing from $95 \mathrm{mT}$ to zero in a Schonstedt demagnetizer (Model GSD-1) modified by a DC-field coil. Subtraction of the high-coercivity baseline remanence from the remanence measured after this treatment yields ARM intensity. Thirtytwo samples were also given pARM along the $y$-axis in the method described by Jackson et al. (1988). The DC-field was switched on over moving windows with a width of $10 \mathrm{mT}$, and centered at 10 -mT intervals.

Low-field magnetic susceptibility $\left(K_{0}\right)$ was measured by using an automated susceptibility anisotropy bridge with a noise level of $10^{-6} \mathrm{SI}$. The machine measured the susceptibility in the three orthogonal directions and took their average to eliminate the effect of anisotropy. Magnetic hysteresis loops were determined using a vibrating sample magnetometer (VSM) with a total sweep time of $15 \mathrm{~min}$. Because samples were mostly saturated at about $300 \mathrm{mT}$, the maximum field was set at $500 \mathrm{mT}$. Curie points were also identified with the VSM. Each measurement took $60 \mathrm{~min}$, and the temperature ranged 
from room temperature to $600^{\circ} \mathrm{C}$, by which temperature all magnetization was lost.

$\mathrm{X}$-ray diffraction was performed to further characterize the magnetic minerals in the samples. Because the magnetic fraction is usually very small, below the resolution of the X-ray diffraction instrument, samples were ground and magnetically separated. Only the magnetic fraction was X-rayed. To improve the separation, each sample powder was mixed with distilled water to make a slurry. Then a bar magnet, covered with a nonmagnetic copper shell, was moved slowly in the slurry, and the magnetic particles on the shell were removed to a small beaker containing distilled water. This process was repeated several times until no more particles were observed on the shell. X-ray diffractometer measurements, using $\mathrm{Cu}-\mathrm{K} \alpha$ radiation as source, covered a $2 \theta$ ranging from $4^{\circ}$ to $70^{\circ}$.

\section{RESULTS}

The results of NRM measurement are shown in Table 1 and Figure 2. As observed for the shipboard magnetic data, there are two low-NRM intensity zones from about 675 to 925 and from 1080 to $1243 \mathrm{mbsf}$ (Fig. 2A). A strongly scattered inclination also appears in these low-intensity zones (Fig. 2B). These two observations suggest that our laboratory sample coverage is complete, and no physical or chemical alteration occurred to the samples during the sampling process, transportation, and storage. Except at shallow depths, the average inclination is about $50^{\circ}$, very close to the $51.7^{\circ}$ expected for a geocentric axial dipole field at the site.

Curie point $\left(T_{\mathrm{c}}\right)$ determination shows that the magnetization generally decreases with increases in temperature and essentially becomes zero when the temperature is higher than $580^{\circ} \mathrm{C}$ (Fig. 3), indicating magnetite as the dominant magnetic mineral. This is also confirmed by the X-ray diffraction measurements. X-ray diffraction patterns of the magnetic fraction show typical magnetite $d$ values $-2.53 \AA(100), 1.49 \AA(40)$, and $2.97 \AA$ (30), where the numbers in parentheses are the relative peak intensities. However, there is a difference in thermomagnetic behavior for samples from the highand low-intensity zones. When heated, samples of the high-intensity zone show a magnetization peak at a temperature of about $450^{\circ} \mathrm{C}$ (Fig. 3A), but this is not seen in the low-intensity samples (Fig. 3B). Similar behavior has previously been found for a number of different minerals, due to either oxidation/reduction or exsolution during heating. For example, Strangway and McMahon (1969) measured the magnetization changes of pyrite with temperature, and found that the magnetization peaked at $450^{\circ} \mathrm{C}$. Moskowitz and Hargraves (1982), and Ellwood et al. (1989) have reported the same behavior with iron-rich clay and carbonate. All these experiments were carried out in the presence of air, resulting in oxidation of $\mathrm{Fe}^{2+}$ to form a stronger magnetic mineral such as maghemite or magnetite. However, our samples were heated in a helium-filled environment, free of oxygen, and oxidation alteration is therefore less likely. Ozima and Larson (1970), and Butler et al. (1976) found that for seafloor basalts, even in a strong vacuum, cation-deficient titanomaghemites or titanomagnetites exsolve on heating to form Ti-rich and Ti-poor lamellae, the latter having a higher $T_{\mathrm{c}}$ and higher room-temperature saturation magnetization. Thus, to the best estimate, titanomaghemite or titanomagnetite may be the mineral causing the magnetization peak when samples of high-intensity were heated, although our experimental conditions were different from those of Ozima and Larson (1970), and Butler et al. (1976).

Saturation magnetization $\left(J_{\mathrm{s}}\right)$ is the best parameter to measure relative magnetic contents in samples, because, unlike ARM and susceptibility, it is not affected by magnetic particle sizes, but only by the magnetic contents. $J_{\mathrm{s}}$ is about $0.05 \mathrm{~A} \cdot \mathrm{m}^{2} / \mathrm{kg}$ in the high-intensity zones, and falls to $10^{-4} \mathrm{~A} \cdot \mathrm{m}^{2} / \mathrm{kg}$ in the low-intensity zones (Fig. 4). Therefore, using the value $92 \mathrm{~A} \cdot \mathrm{m} / \mathrm{kg}$ for the saturation magnetization of magnetite (Stacey and Banerjee, 1974) and ignoring the possible occurrence of titanomaghemite or titanomagnetite in the high-inten-

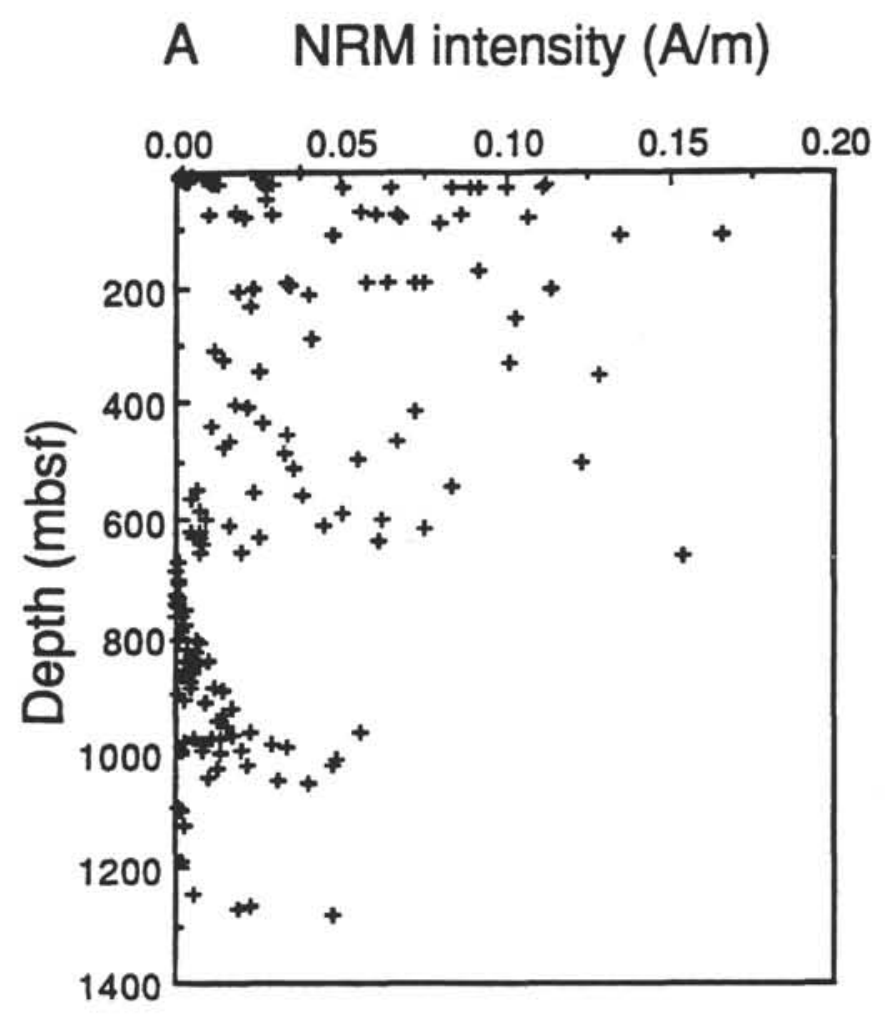

\section{B Inclination (degrees)}

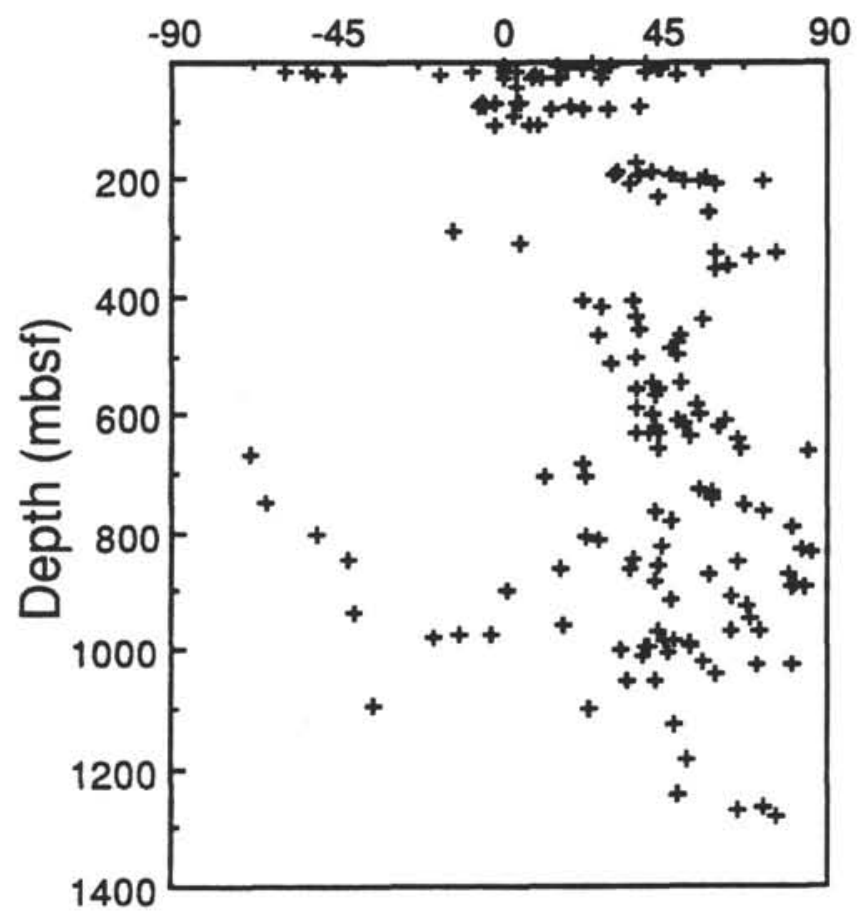

Figure 2. Magnetic results for individual samples. A. Magnetic intensity plot showing a distribution similar to shipboard magnetic measurements (Fig. 1A, -B). B. Inclination plot. 

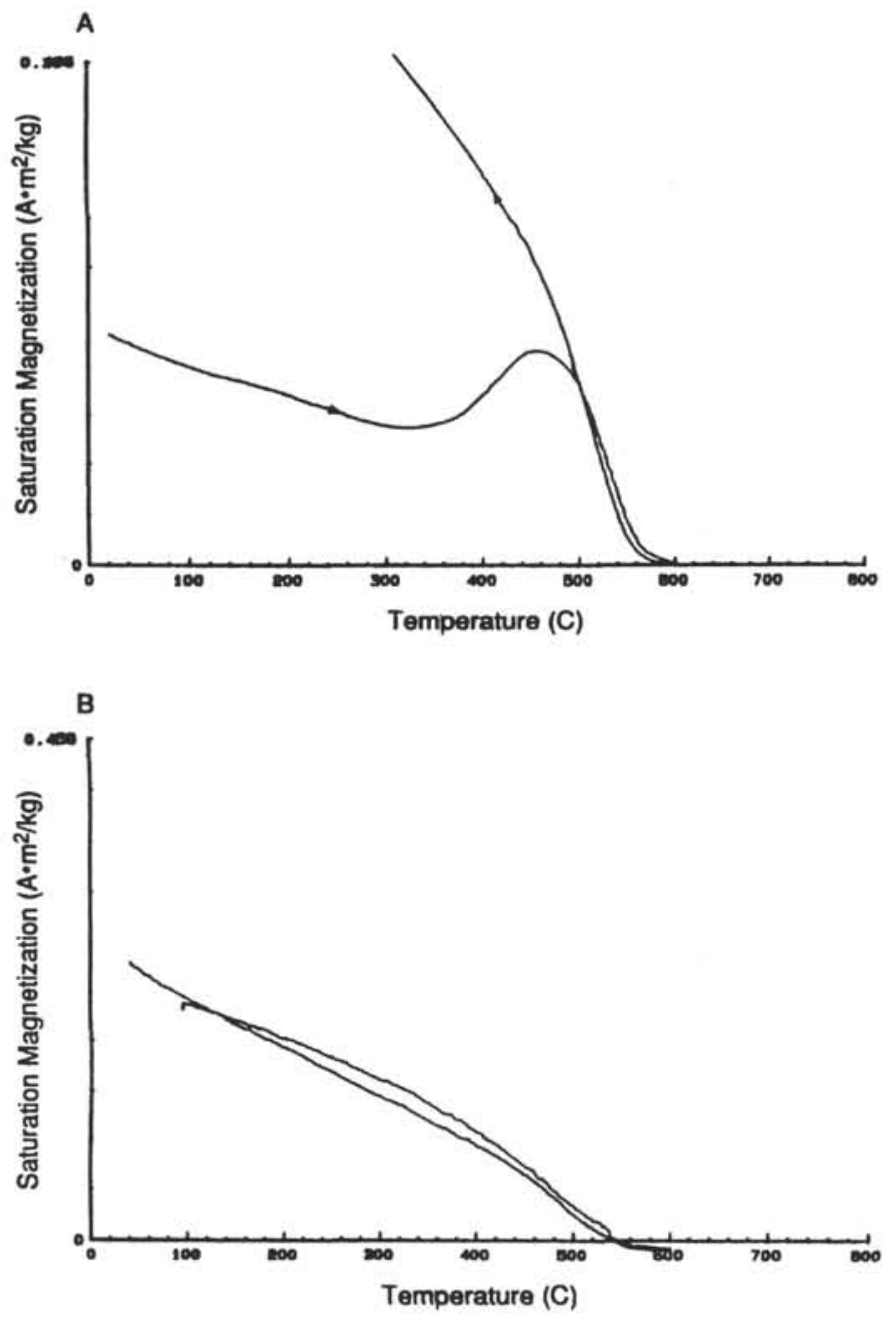

Figure 3. Curie-point measurement. A. Result of sample from high-intensity zone. Note that there is a large peak in the heating curve. B. Result of sample from the low-intensity zone.

sity zones, the magnetite contents are approximately $5 \times 10^{-2} \%$ and $10^{-3} \%$ for high- and low-intensity zones, respectively.

$\mathrm{ARM} / K_{0}$ ratio has been commonly used to determine the relative variation of magnetic grain sizes due to the different sensitivities of ARM and $K_{0}$ to magnetic particle sizes. $K_{0}$ is a weak function of magnetic grain size, whereas ARM is rather sensitive to the presence of relatively fine grains (King et al., 1982), although both depend on magnetic concentration. Therefore, the ratio of ARM to $K_{0}$ normalizes ARM for changes in magnetic concentration and only indicates the grain size variations. Figure 5 shows that the ratios are quite scattered at shallow depth (down to about $675 \mathrm{mbsf}$ ), ranging from 3 to $8 \mathrm{~A} / \mathrm{m}$. Below that, they are clustered between 2 and $3 \mathrm{~A} / \mathrm{m}$ (675-925 mbsf). Further down, the ratios increase rapidly to a maximum value of about $25 \mathrm{~A} / \mathrm{m}$ and then decrease again from about 1080 to 1243 mbsf. This distribution resembles that of NRM intensity (Figs. 1C, -D, and 2A) with smaller values in the low-intensity zones, suggesting larger magnetic particle sizes present in these sediments. However, to use this ratio properly, two assumptions have to be satisfied: (1) sediments should have a single dominant magnetic mineral, and (2) the paramagnetic contribution is negligible. As described before, Curie temperature and X-ray diffraction measurements have shown that magnetite is the dominant magnetic carrier in the samples, which meets the first requirement. $K_{0}$ is composed of ferrimagnetic $\left(K_{\mathrm{f}}\right)$ and paramagnetic $\left(K_{\mathrm{p}}\right)$ susceptibilities. When $K_{0}$ is small $\left(<10^{-3}-10^{-4}\right), K_{\mathrm{p}}$ may be comparable with $K_{\mathrm{f}}$. In that case, a paramagnetic

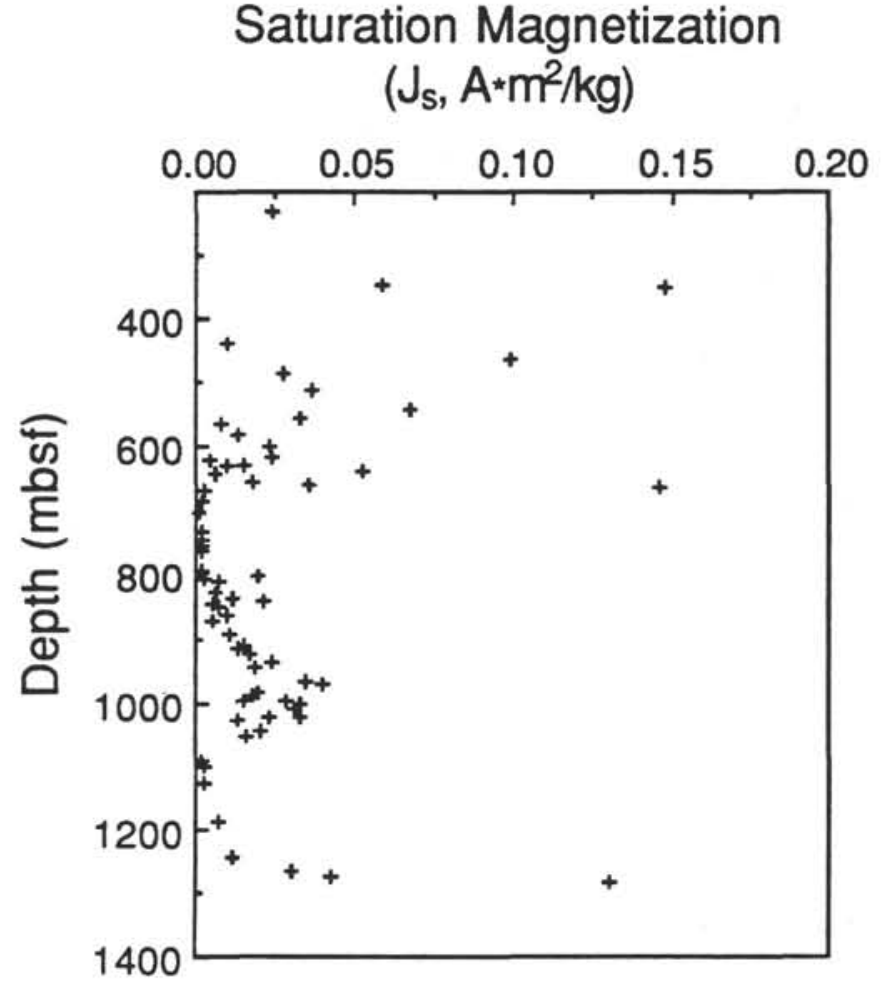

Figure 4. Saturation magnetization measurements $\left(J_{\mathrm{s}}\right)$. It has two low-value intervals corresponding to the low-intensity zones.

correction of $K_{0}$ for $K_{\mathrm{p}}$ is necessary to use ARM $/ K_{0}$ ratios. Figure 6 shows $K_{0}$ variation with depth. In the low-intensity zones, $K_{0}$ decreases greatly to as low as $10^{-4} \mathrm{SI}$, which suggests that our interpretation for grain-size variation based on $\mathrm{ARM} / K_{0}$ needs to be verified after $K_{0}$ is corrected for $K_{\mathrm{p}}$. Such measurements are in progress, and the results will be presented in a subsequent paper. However, magnetic grain-size distribution can also be estimated by pARM measurements (Jackson et al., 1988). For finer grains, the coercivity is higher and the PARM peaks for higher windows, unless the magnetic particles are so fine $(<0.03 \mu \mathrm{m})$ that the coercivity begins to decrease again (Maher, 1988). For our sediments, pARM of high-intensity samples peaks at a much higher window than that of low-intensity samples (Fig. 7A, -B). This result also appears to indicate a large magnetic grain size in the low-intensity zones, consistent with $\mathrm{ARM} / K_{0}$ measurements.

\section{DISCUSSION}

Low NRM intensities can, in general, be caused by either a weak paleomagnetic field or a small magnetic content. The two can be distinguished by the measurements of saturation magnetization, as $J_{\mathrm{s}}$ is directly proportional to magnetic contents in specimens. Figure 4 shows the downhole variation of $J_{s}$. At $675 \mathrm{mbsf}, J_{\mathrm{s}}$ decreases suddenly to about zero, then increases slowly until $925 \mathrm{mbsf}$, and decreases again from 1080 mbsf until 1247 mbsf. This distribution closely mimics that of NRM intensity (Figs. 1C, -D, and 2). The similarity between $J_{\mathrm{s}}$ and NRM intensity suggests that the low-NRM intensity zones in our study are produced by a small magnetic content in the sediments instead of a weak magnetic field.

Low magnetic content can also be due to the dilution by calcium carbonate (Doh et al., 1988). However, this possibility can be ruled out for these samples immediately after a simple calculation. Calcium carbonate content increases from about $10 \%$ to about $40 \%$ in the low-intensity zones (Taira, Hill, Firth, et al., 1991). Therefore, magnetic content can only be diluted by a factor of $1.5(0.9 / 0.6)$. If the low-intensity 


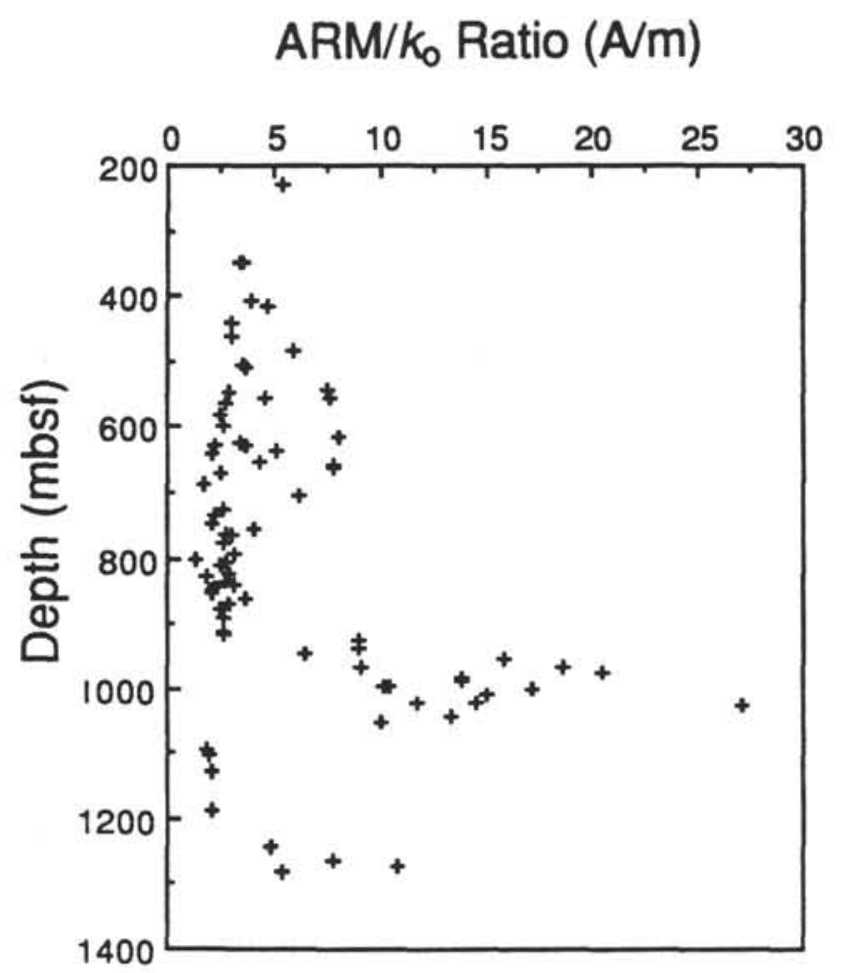

Figure 5. ARM $/ K_{0}$ ratio vs. depth. There are two low-value sections at about 675-925 and 1080-1243 mbsf.

zones were due to this dilution, NRM intensity should have decreased by a factor of 1.5 instead of 1 or 2 orders of magnitude. Apparently, the low-NRM intensity zones originated from some other mechanism.

A smaller magnetic content can also be due to fluctuations in sediment sources or sediment diagenesis. Different sediment sources have variable magnetic contents. For instance, it has been reported that turbidites show a stronger NRM than do hemipelagic sediments (Niitsuma, 1986). Changes in sediment sources can be reflected in sediment grain sizes, color, mineralogy, and texture. According to these characteristics, sediments were divided into different units at Site 808. Figure 8 compares the sediment units and NRM intensity distributions for the depth range $618.3-1243.0 \mathrm{mbsf}$. The first low-intensity zone starts within sediment Unit IVa at 675 mbsf, and this unit ends at 823.7 mbsf, about $100 \mathrm{~m}$ shallower than the first low-intensity zone does. The same applies to the Unit IVb and the second low-intensity zone (1080-1243 mbsf). Clearly, there is no correlation between sediment units and NRM intensities. Thus we must consider alternate explanations, such as alteration of magnetic minerals during diagenesis.

Sediment diagenesis has been considered to influence greatly the preservation of magnetic minerals (Leslie, Hammond, et al., 1990, Leslioe, Lund, et al., 1990; Canfield and Berner, 1987; Karlin and Levi, 1983; Karlin, 1985, 1990). This process takes place through bacterial activity on organic matter. In the top sediment layer where bacteria are abundant, organic matter is oxidized and decomposed. Carbon in organic matter loses electrons to other electron acceptors such as $\mathrm{Fe}^{3+}$ and $\mathrm{SO}_{4}{ }^{2-}$, etc. This results in the dissolution of magnetic minerals and the formation of pyrite. As a consequence, magnetic content and grain size become smaller, producing weak NRM intensities in sediments. All the studies on this subject have suggested that magnetic dissolution only occurs in the top sediment layer of several meters (Leslie, Hammond, et al., 1990, Leslie, Lund, et al., 1990; Canfield and Berner, 1987; Karlin and Levi, 1983; Karlin, 1985, 1990). However, in our study, the first large decrease in NRM intensity is located at $675 \mathrm{mbsf}$, where bacterial activity is much less
Magnetic Susceptibility $\left(k_{0}, \mathrm{SI}\right)$

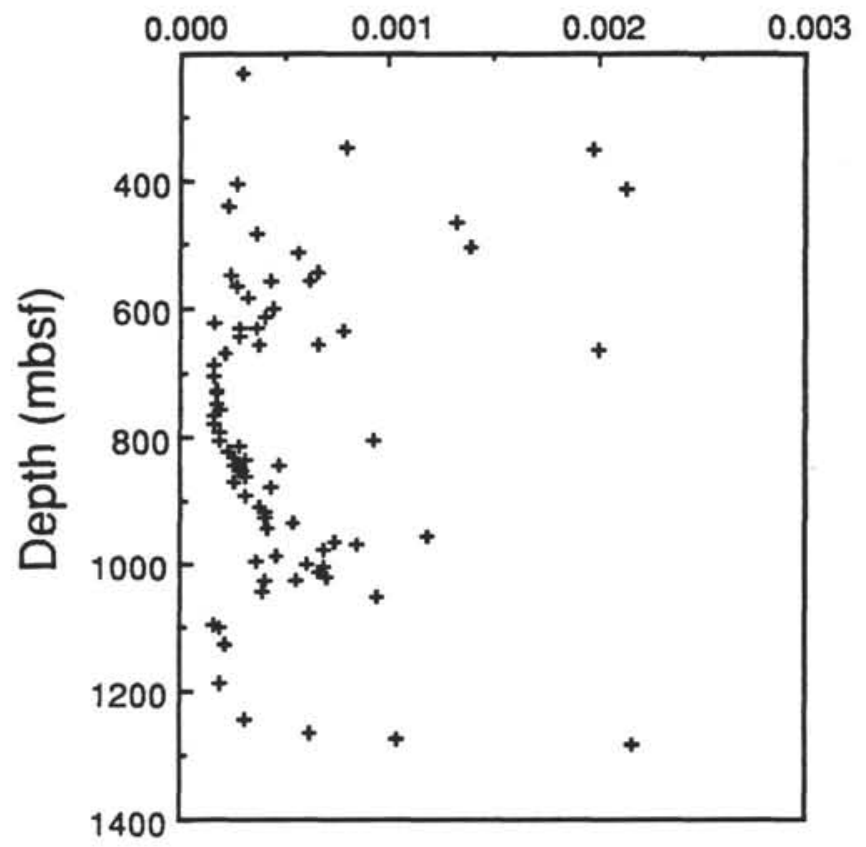

Figure 6. Magnetic susceptibility vs. depth. The plot shows two low-value regions consistent with the low-intensity zones.

intensive. This raises a related question-whether the low-intensity zones first developed at shallow depth and were preserved by the overburden, or whether they developed at depth. As discussed above, organic content and bacterial activity play an important role in the dissolution of magnetic minerals. The organic content in our sediments shows a fairly steady decrease with depth, from $0.86 \%$ to $0.1 \%$ without dramatic changes, as seen in the NRM intensity pattern (Taira, Hill, Firth, et al., 1991). Within a sediment unit, the intensity of bacterial activity is relatively uniform. In other words, when sediments are homogeneous, the organic matter should reach the same degree of maturity if organic decomposition occurs through bacterial activities near the surface, and hence NRM intensity should be fairly stable in each sediment unit. But this is not the case in this study. As shown before, there is no relation between NRM intensities and changes in sedimentary facies. Furthermore, magnetic grain sizes appear larger in the low-intensity zones from the measurements of $\mathrm{ARM} / K_{0}$ ratio and $\mathrm{pARM}$. Figure 5 plots $\mathrm{ARM} / K_{0}$ ratio vs. depth. The ratios are smaller in the low-intensity zones, suggesting larger magnetic grain sizes present (King et al., 1982). pARM measurements (Fig. 7) show that the magnetization peak is reached at a lower AF window for the sample from the low-intensity zone than for the sample from the high-intensity zone, also suggesting low magnetic coercivities and large grain sizes (Jackson et al., 1988). These lines of evidence support later diagenesis in deep sediments, rather than diagenesis at shallow depth through bacterial activity, as the source of the low-intensity zones at Site 808 . The observation of organic geochemistry also appears to suggest the occurrence of diagenesis at depth. A large amount of lightweight hydrocarbon gases were found in the vicinity of the low-intensity zones, indicating the alteration of organic matter in the sediments (Taira, Hill, Firth, et al., 1991).

One interesting observation in our study is that there is a high-intensity zone ( $925-1080 \mathrm{mbsf}$ ) sandwiched into the two low-intensity zones. Note also that this sandwiched zone contains the décolle- 
A

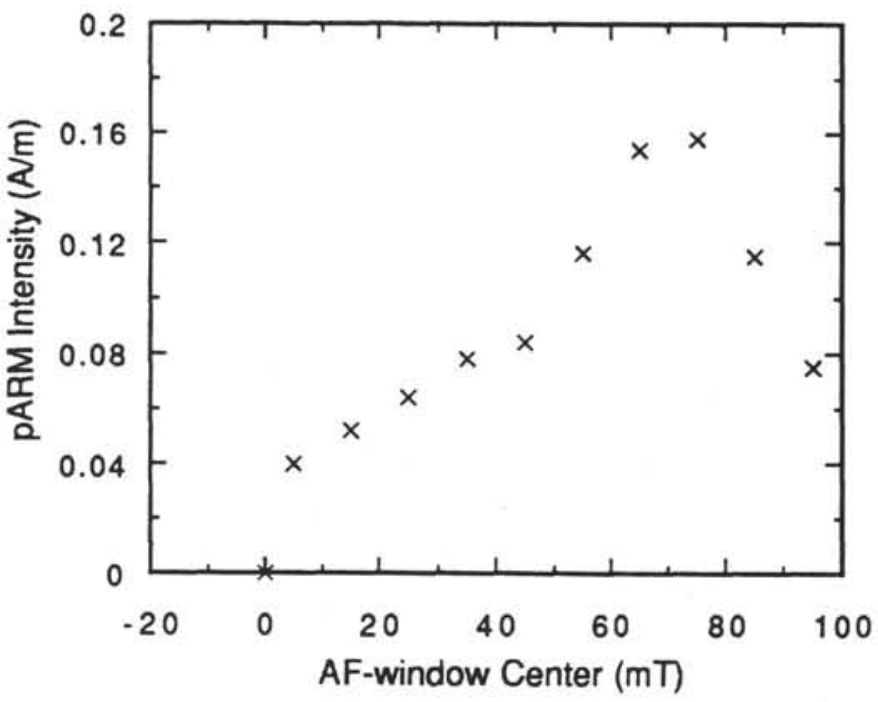

B

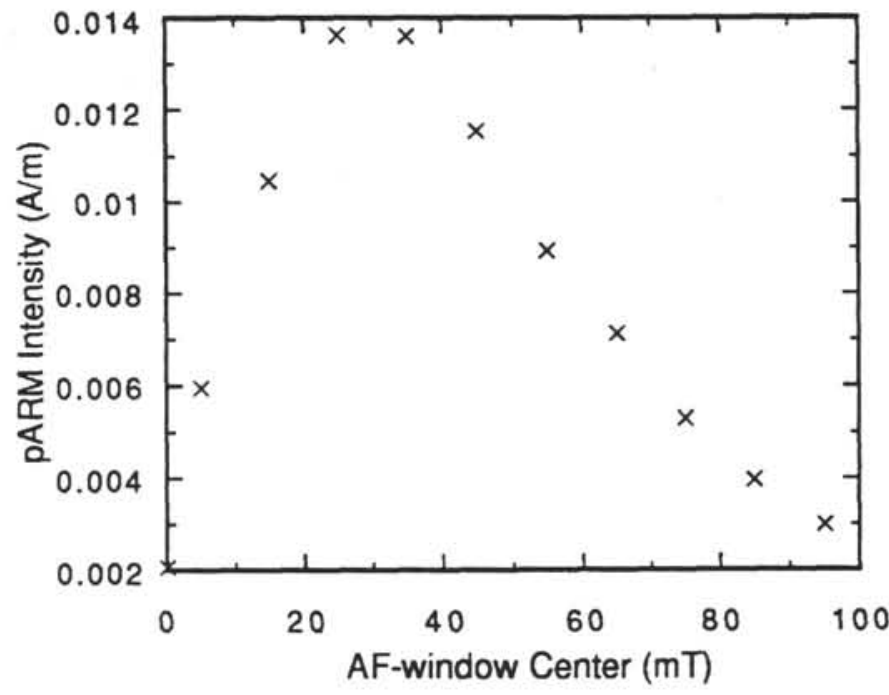

Figure 7. pARM measurements. A. Plot for a sample from high-intensity zone. The peak is at an AF-window center of $75 \mathrm{mT}$. B. Plot for a sample from low-intensity zone. The peak appears at a window center of $25 \mathrm{mT}$.

ment-a major structure in the Nankai Trough (Taira, Hill, Firth, et al., 1991). The décollement is a zone within which thrusting and fracturing have been intensively developed. It has been considered that the décollement has a great influence on hydrologic systems, and is a main water conduit in trench areas (Moore et al., 1988; Moore, 1989). Geochemical evidence from You et al. (this volume) suggests that at least episodic pulses of fluids occur along the décollement in the Nankai prism. Changes in pore water can alter magnetic properties of the sediments (Thomson and Oldfield, 1986). Thus it appears that fluid flow in the Nankai décollement may prevent destruction of magnetic minerals during sediment diagenesis. Alternatively, this high-intensity zone may result from an episode of relatively high input of magnetic minerals into the sediments from detritus or the atmosphere.

For the time being, it is unclear how diagenesis in deep sediments and fluid flow along the décollement may influence the magnetic properties of the sediments. We suggest that the key lies in collaborative research in magnetism, geochemistry, sedimentology, and structural geology.
Further work, including chemical analysis on elements, is in progress and the results will be reported in a forthcoming paper.

\section{ACKNOWLEDGMENTS}

The shipboard magnetic measurements could not have been undertaken without the help of W. H. Owens. The manuscript is much improved because of the comments of B. Moskowitz, C. Hunt, K. Kodama, and other anonymous reviewers. This work is supported by the U.S. Scientist Support Program of JOI. This paper is contribution \#9201 from the Institute for Rock Magnetism, established by the National Science Foundation, W.M. Keck Foundation, and the University of Minnesota.

\section{REFERENCES}

Butler, R.F., Banerjee, S.K., and Stout, J.H., 1976. Magnetic properties of oceanic basalts: evidence from Macquairie Island. Geophys. J. R. Astron. Soc., 47:179-196.

Canfield, D.E., and Berner, R.A., 1987. Dissolution and pyritization of magnetite in anoxic marine sediments. Geochim. Cosmochim. Acta, 51:645-659.

Doh, S.-J., King, J.K., and Leinen, M., 1988. A rock-magnetic study of giant piston core LL44-GPC3 from the Central North Pacific and its paleoceanographic implications. Paleoceanography, 3:89-111.

Ellwood, B.B., Burkart, B., Rajeshwar, K., Darwin, R.L., Neeley, R.A., McCall, A.B., Long, G.J., Buhl, M.L., and Hickcox, C.W., 1989. Are the iron carbonate minerals, anherite, and ferroan dolomite, like siderite, important in paleomagnetism? J. Geophys. Res., 94:7321-7331.

Jackson, M., Gruber, W., Marvin J., and Banerjee, S.K., 1988. Partial anhysteretic remanence and its anisotropy: application and grainsize-dependence. Geophys. Res. Lett., 15:440-443.

Kagami, H., Karig D.E., and Coulbourn W.T., et al., 1986. Init. Repts. DSDP, 87: Washington (U.S. Govt. Printing Office).

Karlin, R., 1990. Magnetic mineral diagenesis in suboxic sediments at Bettis site W-N, NE Pacific Ocean. J. Geophys. Res., 95B:4421-4436.

Karlin, R., and Levi, S., 1983. Diagenesis of magnetic minerals in recent hemipelagic sediments. Nature, 303:327-330.

- 1985. Geochemical and sedimentological control of the magnetic properties of hemipelagic sediments. J. Geophys. Res., 90B:10373-10392.

King, J.W., Banerjee, S.K., Marvin, J., and Ozdemir, O., 1982. A comparison of different magnetic methods for determining the relative grain size of magnetite in natural materials: some results from lake sediments. Earth Planet. Sci. Lett., 59:404-419.

Leslie, B.W., Hammond, D.E., Berelson, W.M., and Lund, S., 1990. Diagenesis in anoxic sediments from the California Continental Borderland and its influence on iron, sulfur, and magnetite behavior. J. Geophys. Res., 95:4453-4470.

Leslie, B.W., Lund S., and Hammond, D.E., 1990. Rock magnetic evidence for the dissolution and authigenic growth of magnetic minerals within anoxic marine sediments of the California Continental Borderland. J. Geophys. Res., 95:4437-4452.

Maher, B.A., 1988. Magnetic properties of some synthetic sub-micron magnetites. Geophys. J., 94:83-96.

Mascle, A., and Moore, J.C., et al., 1988. Proc. ODP, Init. Repts., 110: College Station, TX (Ocean Drilling Program).

Moore, J.C., 1989. Tectonics and hydrogeology of accretionary prisms: role of the decollement zone. J. Struct. Geol,. 11:95-106.

Moore, J.C., and Scientific Party of Leg 110, 1988. Tectonics and hydrogeology of the northern Barbados Ridge: results from Ocean Drilling Program Leg 110. Geol. Soc. Am. Bull., 100:1578-1593.

Moskowitz, B.M., and Hargraves, R.B., 1982. Magnetic changes accompanying the thermal decomposition of nontronite (in air) and its relevance to Martian mineralogy. J. Geophys. Res., 87:10115-10128.

Niitsuma, N., 1986. Paleomagnetic results, Nankai Trough and Japan Trench. In Kagami, H., Karig, D.E., and Coulbourn, W.C., et al., Init. Repts. DSDP, 87: Washington (U.S. Govt. Printing Office), 757-786.

Ozima, M., and Larson, E.E., 1970. Low and high temperature oxidization of titanomagnetites in relation to irreversible changes in the magnetic properties of submarine basalts. J. Geophys. Res., 75:1003-1016.

Rangin, C., Silver, E. A., von Breymann, M.T., et al., 1990. Proc. ODP, Init. Repts., 124: College Station, TX (Ocean Drilling Program). 
Stacy, F.D., and Banerjee, S.K., 1974. The Physical Principles of Rock Magnetism: New York (Elsevier).

Strangway, D.W., and McMahon, B.E., 1969. Magnetic properties of minerals from the Red Sea thermal brines. In Degens, E.T., and Ross D.A. (Eds.), Hot Brines and Recent Heavy Metal Deposits in the Red Sea: Berlin (Springer-Verlag), 460-473.

Taira, A., Hill, I., Firth, J.V., et al., 1991. Proc. ODP, Init. Repts., 131: College Station, TX (Ocean Drilling Program).
Thomson, R., and Oldfield, F., 1986. Environmental Magnetism: London (Allen and Unwin).

Date of initial receipt: 30 September 1991

Date of acceptance: 2 March 1992

Ms 131SR-128

$618.3 \mathrm{~m}$

$823.7 \mathrm{~m}$

$1243.0 \mathrm{~m}$

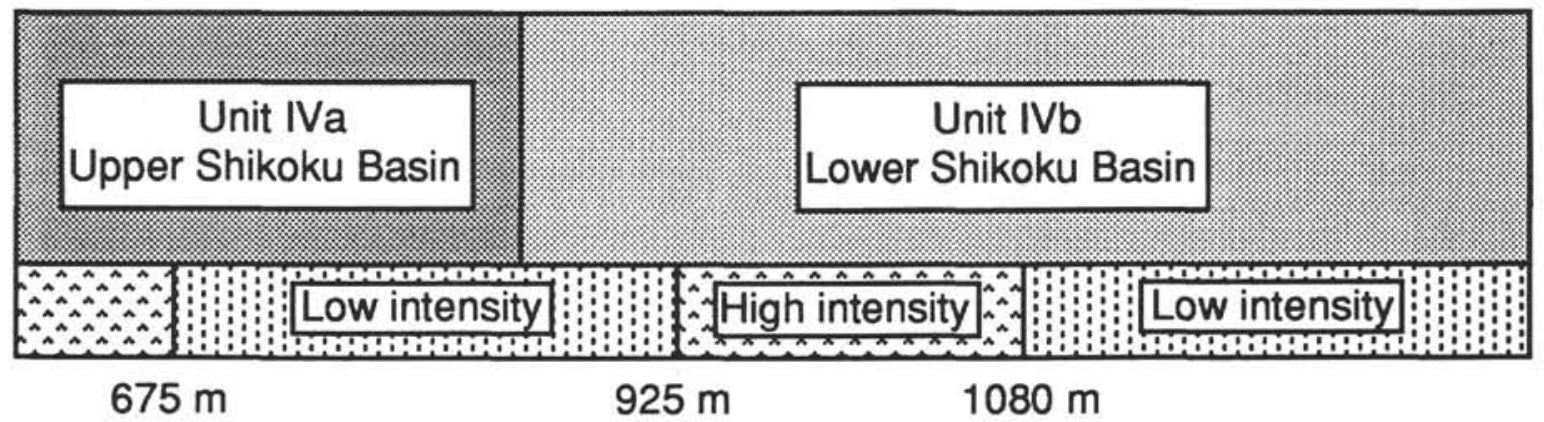

Figure 8. A comparison of sediment units and magnetic intensity zones. Note that there is no obvious relation between the two. 